\title{
Comparison of single spot urinary albumin-creatinine ratio with 24- hour urinary protein excretion in women with preeclampsia
}

\author{
Indu Kaul, Bawa Ram Bhagat, Deepika Sharma, Gagan Singh*
}

Department of Obstetrics and Gynecology, Government Medical College, Jammu, Jammu and Kashmir, India

Received: 12 March 2018

Accepted: 05 April 2018

\section{*Correspondence:}

Dr. Gagan Singh,

E-mail: gaganbhau@gmail.com

Copyright: (C) the author(s), publisher and licensee Medip Academy. This is an open-access article distributed under the terms of the Creative Commons Attribution Non-Commercial License, which permits unrestricted non-commercial use, distribution, and reproduction in any medium, provided the original work is properly cited.

\begin{abstract}
Background: The measurement of albumin: creatinine ratio (ACR) in a spot urine sample avoids the influence of variation in urinary solute concentration and provides a more convenient and rapid method to assess protein excretion. The aim of this study was to evaluate urinary spot ACR as a new marker for proteinuria and to study its correlation and accuracy in comparison with 24-hour urinary protein.

Methods: The prospective one-year study was conducted on 100 pregnant women, 18-40 years, >20 weeks gestation with a diagnosis of preeclampsia. A spot midstream urine sample was taken for detection of albuminuria by dipstick method. Another spot sample was taken for detection and calculation of spot ACR. The 24-hour urine collection was taken immediately afterward to evaluate 24-hour urinary protein excretion.

Results: A positive linear relation exists between ACR and 24-hour urinary protein excretion The ROC revealed cutoff of 20.4 with $88.5 \%$ sensitivity, $75 \%$ specificity, $98.8 \%$ positive predictive value and $21.4 \%$ negative predictive value. Spot urinary ACR > 20.4 correctly identified women having 24-hour urinary protein excretion in excess of 0.3 gm/DL.

Conclusions: A strong correlation exists between single spot urinary ACR with 24-hour urinary protein excretion in women with preeclampsia.
\end{abstract}

Keywords: 24-hour urinary protein excretion, Albumin-creatinine ratio, Preeclampsia

\section{INTRODUCTION}

Hypertensive disorders are frequently encountered complications in pregnancies and are associated with increased risk of both adverse maternal and fetal outcome. Overall $10-15 \%$ of maternal death are directly associated with preeclampsia and eclampsia. ${ }^{1}$

Preeclampsia is a disorder of widespread vascular endothelial dysfunction and vasospasm that occur after 20 weeks of gestation and can present as late as 4-6 week postpartum. ${ }^{2}$ The etiology of preeclampsia is unknown but thought to be related to hypoxia in the placenta due to abnormal placentation. Mild preeclampsia occurs in approximately $15 \%$ of pregnancies and severe in $1-2 \% .^{3}$ It complicates $10 \%$ of pregnancies in developing countries and responsible for about 76000 maternal deaths every year. ${ }^{4,5}$

Minimum criteria for preeclampsia include blood pressure $>140 / 90 \mathrm{~mm} \mathrm{Hg}$ after 20 weeks gestation, proteinuria $>300 \mathrm{mg} / 24$ hours or $>1+$ dipstick. $^{2}$

The measurement of protein excretion in a 24-hour urine collection is used as gold standard for the diagnosis and follow-up of pathological urinary excretion. However, the standard practice of collecting a 24-hour urine for a protein is cumbersome, time consuming and inconvenient 
and only some women can have managed as outpatients and collect a 24-hr urine sample. ${ }^{6}$ The dipstick analysis, using visual reagent strips, is quick, portable and easy to do but the test has relatively high false positive and false negative rate. ${ }^{7}$ Spot urinary ACR overcomes these false positive and false negative rates. ${ }^{6}$ The measurement of ACR in a spot urine sample avoids the influence of variation in urinary solute concentration and provide a more convenient and rapid method to asses protein excretion. Several international organizations have accepted the spot urine ACR as a reasonable method for the identification of significant proteinuria $(>0.3 \mathrm{~g} / 24 \mathrm{~h})$ during pregnancy..$^{8-10}$

\section{METHODS}

The present study was conducted on pregnant women attending outpatient department or admitted in Department of Obstetrics and Gynaecology, Government Medical College Jammu for a period of one year (October 2014 to September 2015). A total of 100 patients were selected according to inclusion criteria (1840yrs of age, $>20$ weeks gestation) and excluding women with known kidney disease, connective tissue disorders, pre-existing diabetes, gestation diabetes and bacteriuria.

The patients were subjected to detailed history and clinical examination including general physical, Obstetrical and systemic examination. All the investigation including haemoglobin, bleeding time, clotting time, routine urine examination, prothrombin time, PTI, platelet count, renal function test, liver function test and urine for albumin, urine for creatinine, 24-hour urinary protein excretion and spot urinary ACR were noted down.
A spot midstream urine sample was taken for detection of albuminuria by dipstick method. Another spot sample was taken for detection and calculation of spot ACR. The 24-hour urine collection was taken immediately afterward to evaluate 24-hour urinary protein excretion. Only one 24-hr urine collection per women was included in the analysis.

The data was analysed using statistical software MS Excel and SPSS 17.0 for window. Correlation was assessed by Pearson method. Correlation coefficient and regression equation calculated using least square method. Scatter diagram was used to display the relationship between single spot urinary ACR and $24 \mathrm{hr}$ urinary protein excretion. ROC curve was drawn and area under curve calculated.

\section{RESULTS}

A total of 100 patients were studied based on inclusion and exclusion criteria for a period of one year and following observations were made, mean age of patient with preeclampsia was $26.71 \pm 3$. Overall, $87 \%$ patient had mild preeclampsia (SBP/DBP; >140/>90mm Hg), $13 \%$ had severe preeclampsia (SBP/DBP; >160/>110mm Hg).

When mean spot urinary albumin level, mean spot urinary creatinine level, mean 24-hour urinary protein excretion level and mean spot urinary ACR were compared between patients with mild $(n=87)$ and severe preeclampsia $(n=13)$, the study found significantly higher level of mean albumin level, mean 24-hr protein excretion level and mean spot urinary ACR in patients with severe preeclampsia (Table 1).

Table 1: Comparison between patients with mild and severe preeclampsia.

\begin{tabular}{|c|c|c|c|}
\hline Variable & $\begin{array}{l}\text { Mild } \\
\text { Pre-eclampsia } \\
(\mathrm{n}=87)\end{array}$ & $\begin{array}{l}\text { Severe } \\
\text { Pre-eclampsia } \\
(n=13)\end{array}$ & $\begin{array}{l}\text { Statistical } \\
\text { Inference } \\
\text { (Student s t- test) }\end{array}$ \\
\hline Spot urinary albumin $(\mathrm{mg} / \mathrm{dL})($ Mean \pm Standard deviation $)$ & $192.05 \pm 120.75$ & $759.4 \pm 235.09$ & $\begin{array}{l}t=13.64 \\
p=0.0001\end{array}$ \\
\hline $\begin{array}{l}\text { Spot urinary creatinine (mmol/dL) } \\
\text { (Mean } \pm \text { Standard deviation) }\end{array}$ & $5.27 \pm 1.14$ & $5.30 \pm 0.96$ & $\begin{array}{l}t=0.09 \\
p=0.92\end{array}$ \\
\hline $\begin{array}{l}\text { 24-hour urinary protein excretion }(\mathrm{g} / \mathrm{L}) \\
\text { (Mean } \pm \text { Standard deviation) }\end{array}$ & $0.40 \pm 0.22$ & $3.36 \pm 2.00$ & $\begin{array}{l}t=13.64 \\
p=0.0001\end{array}$ \\
\hline $\begin{array}{l}\text { Spot urinary albumin creatinine ratio }(\mathrm{mg} / \mathrm{mmol}) \\
\text { (Mean } \pm \text { Standard deviation) }\end{array}$ & $36.35 \pm 21.34$ & $140.56 \pm 32.72$ & $\begin{array}{l}t=15.21 \\
p=0.0001\end{array}$ \\
\hline
\end{tabular}

Figure 1 shows that a positive linear relation exists between ACR and 24-hr urinary protein excretion. The correlation can be classified as very strong as evident by Pearson Coefficient $r$ as 0.836 . The coefficient of determination i.e. $\mathrm{R}^{2}=0.70$ which means that $70 \%$ of the variation in one variable can be explained by another.
The regression equation could be written as $\mathrm{y}=\mathrm{a}+\mathrm{bx}$ or $0.484+0.26 \mathrm{x}$, where $\mathrm{y}$ denotes the dependent variable (24-hr urinary protein excretion) a as a intercept or change in $\mathrm{y}$ when $\mathrm{x}=0$ and $\mathrm{b}$ being regression coefficient (change in unit $\mathrm{y}$ given change per unit $\mathrm{x}$ ) 
The receiver operating characteristic curve analysis reveal cut-off as 20.4. A cut-off of 20.4 seems best tradeoff between sensitivity $88.5 \% \quad(80.6-93.4 \%)$ and specificity $75 \%(30-95.4 \%)$. The area under curve is 0.836 with confidence interval (CI, 0.64-1.00), which is indicative of excellent discriminating capability of the cut-off. Positive predictive value is $98 \%$ (93.7-99.7\%), negative predictive value is $21.4 \% \quad(7.57-47.5 \%)$, Likelihood ratio (positive) is $3.54 \quad(0.49-25.2 \%)$. Likelihood ratio (negative) is $0.15(0.10-0.22 \%)$ (Table2).

Table 2: Predictive index for albumin creatinine ratio for $0.3 \mathrm{gm} / 24$ hour of protein excretion.

\begin{tabular}{|c|c|c|c|c|c|c|c|c|}
\hline Variable & $\begin{array}{l}\text { AUC } \\
(95 \% \text { CI })\end{array}$ & $\begin{array}{l}\text { Sensitivity } \\
(\%)\end{array}$ & $\begin{array}{l}\text { Specificity } \\
(\%)\end{array}$ & $\begin{array}{l}\text { PPV } \\
(\%)\end{array}$ & $\begin{array}{l}\text { NPV } \\
(\%)\end{array}$ & LR+ & LR- & $\begin{array}{l}\text { Accuracy } \\
(\%)\end{array}$ \\
\hline $\begin{array}{l}\text { Spot urinary } \\
\text { ACR }\end{array}$ & $0.836(0.64-1.00)$ & 88.5 & 75 & 98.8 & 21.4 & 3.5 & 0.15 & 88 \\
\hline
\end{tabular}

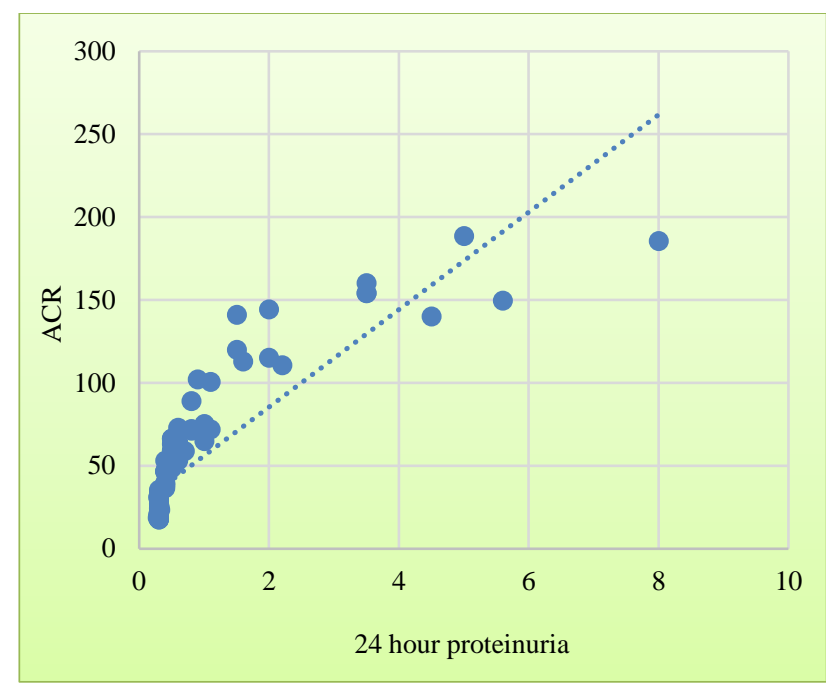

Figure 1: Scatter diagram showing correlation between spot urinary albumin creatinine ratio (ACR) and 24-hour urinary protein excretion.

Table 3 shows that spot urinary ACR correctly identifies majority of women having 24-hr urinary protein excretion in excess of $0.3 \mathrm{gm} / \mathrm{L}$ and therefore can be gainfully used as a screening test.

Table 3: Accuracy and ability of spot urinary albumin creatinine ratio in predicting 24 -hour urinary protein excretion.

\begin{tabular}{|c|c|c|c|}
\hline \multirow{2}{*}{$\begin{array}{l}\text { Spot urinary } \\
\text { albumin- } \\
\text { creatinine ratio }\end{array}$} & \multicolumn{2}{|c|}{$\begin{array}{l}24 \text { hours urinary } \\
\text { protein excretion }\end{array}$} & \multirow{2}{*}{ Total } \\
\hline & $\begin{array}{l}\geq 0.3 \\
\mathrm{gm} / \mathrm{L}\end{array}$ & $\begin{array}{l}<0.3 \\
\mathrm{gm} / \mathrm{L}\end{array}$ & \\
\hline$\geq 20.4$ & 85 & 1 & 86 \\
\hline$<20.4$ & 11 & 3 & 14 \\
\hline Total & 96 & 4 & 100 \\
\hline
\end{tabular}

The clinician can be quite confident in predicting that the patient has urinary protein excretion in excess of $0.3 \mathrm{gm} / \mathrm{L}$ if the test is reported positive i.e spot urinary ACR is more than 20.4. In other words, the likelihood of women having urinary protein excretion in excess of $0.3 \mathrm{gm} / \mathrm{L}$ is 3.5 times higher if test is positive than when it is negative.

\section{DISCUSSION}

As per Moiety et al, the mean spot urinary albumin level in 50 patients with severe preeclampsia was $3976.97 \pm 5580.22 \mathrm{mg} / \mathrm{L}$ and in 50 patients with mild preeclampsia was $717.99 \pm 1273.03 \mathrm{mg} / \mathrm{L}$ with $\mathrm{p}=0.001$ which is not consistent with the present study. ${ }^{11}$ Huang et al reported mean spot urinary creatinine levels in patients with mild preeclampsia to be $51.8 \pm 8.97 \mathrm{mmol} / \mathrm{L}$ and $77.7 \pm 59.4 \mathrm{mmol} / \mathrm{L}$ in severe preeclampsia, which is similar to the present study. ${ }^{12}$ Present result are consistent with Gao et al where 24 hours urinary protein excretion levels in mild and severe preeclampsia was $700 \pm 160 \mathrm{mg}$ and $4800 \pm 2200 \mathrm{mg}$ respectively with $\mathrm{p}<0.05 .^{13}$ As per Aggarwal et al the mean protein excretion was $1.33 \mathrm{~g} / \mathrm{L}$, which is consistent with the present study. ${ }^{14}$

As per Huang et al the mean standard deviation of spot urinary ACR levels in patient with mild preeclampsia was $72.68 \pm 12.4 \mathrm{mg} / \mathrm{mmol}$ as compared to that in patient with severe preeclampsia $401.2 \pm 345.1 \mathrm{mg} / \mathrm{mmol}$ respectively $(p<0.05)$ which is not consistent with the present study. ${ }^{12}$ The reason for this very high value can be the higher proportion of severe preeclampsia patients in their sample.

Our study is consistent with Ray et al with $r=0.94$ and $\mathrm{p}<0.0001$ and $\mathrm{Al}$ et al, with a cut-off protein creatinine ratio greater than 0.19 or $21 \mathrm{mg} / \mathrm{mmol}$ as a predictor of significant proteinuria, sensitivity and specifity were $85 \%$ and $73 \%$ respectively. ${ }^{15,17}$ Positive and negative predictive value of the test were $46 \%$ and $95 \%$ respectively.

Our result are also consistent with Huang et al, optimal spot ACR cut-off point was $22.8 \mathrm{mg} / \mathrm{mmol}$ for $0.3 \mathrm{~g} / 24$ hour of protein excretion (mild preeclampsia) with a 
sensitivity and specifity of $82.4 \%$ and $99.4 \%$ respectively and $155.6 \mathrm{mg} / \mathrm{mmol}$ for $2 \mathrm{~g} / 24$ hour of protein excretion (severe preeclampsia) with a sensitivity and specifity of $90.6 \%$ and $99,6 \%$ respectively. ${ }^{12}$ Cut-off of the present study is almost similar with that of Wilkinson et al, the authors concluded that both PCR and ACR are good rule out tests for significant proteinuria in pregnancy using cut-off point of $<20 \mathrm{mg} / \mathrm{mmol}$ and $<2.5 \mathrm{mg} / \mathrm{mmol}$. $^{18}$

In another study by Nisell et al, the optimal cut-off of ACR value of $27 \mathrm{mg} / \mathrm{mmol}$ the sensitivity, specificity, positive and negative predictive value for detecting albuminuria $>300 \mathrm{mg} / 24$ hour were: $95,100,100$ and $86 \%$ respectively which is comparable with the present study. ${ }^{19}$ In another study by Heerspink et al, spot urinary micro ACR cut-off of $>30 \mathrm{mg} / \mathrm{g}(3.4 \mathrm{mg} / \mathrm{mmol})$ is considered as positive for significant proteinuria and correlate well with 24-hour urine protein with sensitivity of $94 \%$ and specifity of $98 \% .^{20}$

Cut-off of our study did not correlate with Moiety et al. ${ }^{11}$ cut-off value for ACR for this group of patients was calculated to be $14.65 \mathrm{mg} / \mathrm{mmol}$, above which severity of disease was highly probable. The sensitivity and specifity were $100 \%$ and $58 \%$ respectively. The positive predictive value was $70.4 \%$ and negative predictive value was $100 \%$. Cut-off of the present study also did not correlate with the threshold of Lamontagne et al, the study concluded that protein creatinine ratio threshold of $30 \mathrm{mg} / \mathrm{mmol}$ reliably identifies significant proteinuria, but its reliability is reduced in first morning samples. ${ }^{16}$ The median of protein to creatinine ratio in this study was 24 $\mathrm{mg} / \mathrm{mmol}$ (range 0 to 108).

The cut-off in the present study was lower than that reported in other studies. The underlying reason for lower cut-off may be because of higher proportion of patients with mild preeclampsia ( $87 \%$ ). This could also be due to different physiological reasons such as patients' hydration status, sample contamination with vaginal secretion and/or blood, infection, $\mathrm{pH}$ and specific gravity could contribute to the deviation of the result.

\section{CONCLUSION}

The study concludes that the gold standard 24-hour urinary assessment of albuminuria in preeclamptic women can be substituted with a single spot urinary ACR.

Funding: No funding sources

Conflict of interest: None declared

Ethical approval: The study was approved by the Institutional Ethics Committee

\section{REFERENCES}

1. Carty DM, Delles C, Dominiczak AF. Preeclampsia and future maternal health. $\mathrm{J}$ Hypertension. 2010;28:1349-55.
2. Lim KH, Steinberg G. Preeclampsia: practice essentials, overview, pathophysiology. 2016. Available http://emedicine.medscape.com/article/1476919overview. Accessed $26^{\text {th }}$ November 2016.

3. Aziz R, Mehmoob T. Relation between preeclampsia and cardiac enzymes. ARYA Atherosclerosis J. 2008;4(1):29-32.

4. Grill S, Rusterholz C, Zanetti-Dallenbach R, Tercanli S, Holzgreve W, Hahn S, et al. Potential markers of preeclampsia: a review. Reprod Biol Endocrinol. 2009;7:10.

5. Kuklina EV, Ayala C, Callaghan WM. Hypertensive disorder and severe obstetric morbidity in the United States. Obstet Gynecol. 2009;113(6):1299-306.

6. National Institute for Health and Clinical Excellence Clinical Guideline. Antenatal care: routine care for the healthy pregnant woman. 2008. Available at http://www.nice.org.uk/guidance/cg62 Accessed 26 ${ }^{\text {th }}$ November 2016.

7. Cote AM, Firoz T, Mattman A, Lam EM, Dadelszen VP, Magee LA. The 24-hour urine collection: gold standard or hostorical practice? Am J Obst Gynecol. 2008;199:e1-e6.

8. Waugh JJS, Bell SC, Kilby MD. Optimal bedside analysis for the detection of proteinuria in hypertensive pregnancy: a study of diagnostic accuracy. Br J Obs Gynaecol. 2005;112(4):412-7.

9. Lindheimer MD, Taler SJ, Cunningham FG. ASH position paper: hypertension in pregnancy. J Clin Hypertens (Greenwich). 2009;11:214-25.

10. Lowe SA, Brown MA, Dekker GA, Gatt S, McLintock CK, McMohan LP, et al. Guidelines for the management of hypertensive disorder of pregnancy 2008. Aust N Z J Obs Gynaecol. 2009;49:242-6.

11. Moiety FS, Mohamed ESEB, Attar RE, Kaffash DE. Albumin to creatinine ratio in a random urine sample: Correlation with severity of preeclampsia. Alexandria J Med. 2014;50(2):139-42.

12. Huang Q, Gao Y, Yu Y, Wang W, Wang S, Zhong M. Urinary spot albumin:creatinine ratio for documenting proteinuria in women with preeclampsia. Rev Obs Gynecol. 2012;5(1):9-15.

13. Gao YF, Huang QT, Zhong M, Wang Y, Wang W, Wang ZJ, et al. Diagnostic value of random spot albuminuria to creatinine ratio in women with preeclampsia. Zhonghua $\mathrm{Fu}$ Chan $\mathrm{Ke} \mathrm{Za}$ Zhi. 2012;47(3):166-70.

14. Aggarwal N, Suri V, Saxena S, Kohli HS. A prospective comparison of random urine proteincreatinine ratio versus 24-hour urine protein in women with preeclampsia. Medscape J Med. 2008;10(4):98.

15. Ray R, Banerjee T, Mukherjee P. Evaluation of spot urine protein creatinine ratio versus 24-hour urine protein in diagnosis of hypertensive disorders of pregnancy. IOSR-JDMS. 2015;14(2):44-7.

16. Lamontagne A, Cote AM, Rey E. The urinary protein to creatinine ratio in Canadian women at risk 
of preeclampsia: Does the time of day of testing matter? J Obs Gynaecol Can. 2014;36(4):303-8.

17. Al RA, Baykal C, Karacay O, Geyik PO, Altun S, Dolen I. Random urine protein:creatinine ratio to predict proteinuria in new onset mild hypertension in late pregnancy. Obstet Gynecol. 2004;104(2):367-71.

18. Wilkinson C, Lappin D, Vellinga A, Heneghan HM, Hara R, Monaghasn J. Spot urinary protein analysis for excluding significant proteinuria in pregnancy. $\mathrm{J}$ Obstet Gynecol. 2013;33(1):24-7.

19. Nisell H, Trygg M, Back R. Urine albumin creatinine ratio for the assessment of albuminuria in pregnancy hypertension. Acta Obstetricia Gynecologica Scandinavica. 2006;85(11):1327-30.
20. Heerspink HJL, Brinkman JW, Bakker SJL, Gansevoort RT, de Zeeuw D. Update of microalbuminuria as a biomarker in renal and cardiovascular disease. Curr Opin Nephrol Hypertens. 2006;15:631-6.

Cite this article as: Kaul I, Bhagat BR, Sharma D, Singh G. Comparison of single spot urinary albumincreatinine ratio with 24 -hour urinary protein excretion in women with preeclampsia. Int J Reprod Contracept Obstet Gynecol 2018;7:1929-33. 